\title{
EXPOSURE ASSESSMENT TO ESSENTIAL ELEMENTS THROUGH THE CONSUMPTION OF CANNED FISH IN SERBIA
}

\author{
Jelena Petrovic', Milica Jovetic', Milica Štulić', Azra Redžepović-Đorđević', \\ Dragan Vujadinović ${ }^{2}$, Ilija V. Djekic ${ }^{3}$, Igor B. Tomasevic ${ }^{3 *}$ \\ Center for Food Analysis, Belgrade, Serbia \\ University of East Sarajevo, Faculty of Technology, Zvornik, Bosnia \& Herzegovina \\ ${ }^{3}$ University of Belgrade, Faculty of Agriculture, Belgrade, Serbia
}

\begin{abstract}
Keywords: exposure assessment, Monte Carlo analysis, essential elements, estimated daily intake, canned fish Abstract

The aim of this study was to provide a quantitative exposure assessment to essential elements through the consumption of canned fish in Serbia. This objective was fulfilled by analyzing content of essential elements in canned fish and by using data from a food consumption survey. Consumption survey of canned fish was designed and performed to general principles and EFSA guidelines on data collection of national food consumption. The questionnaire was performed on 1,000 respondents during 2018. Determination of copper, zinc and iron levels were performed on 454 canned fish and seafood samples divided into four groups (canned tuna, canned sardines, canned other sea fish and canned seafood) during five consecutive years (2014-2018). This study showed significant association between sex, BMI and weight and consumption patterns. Obtained average weekly consumption of canned fish confirms our assumption that consumption of canned fish is significant in Serbia. Zinc and iron were found in all 454 samples (100\%), and copper in 222 samples (48.9\%). The average obtained concentration in all samples were $1.268 \mathrm{mg} \mathrm{kg}^{-1}$ for Cu, $5.661 \mathrm{mg}$ $\mathrm{kg}^{-1}$ for $\mathrm{Zn}$ and $9.556 \mathrm{mg} \mathrm{kg}^{-1}$ for Fe. The highest concentration for all three minerals were found in canned sardines (Cu - $6.49 \mathrm{mg}$ $\mathrm{kg}^{-1}, \mathrm{Zn}-37.2 \mathrm{mg} \mathrm{kg}^{-1}$ and $\mathrm{Fe}-21.8 \mathrm{mg} \mathrm{kg}^{-1}$ ). Obtained mean exposure to intake of copper, zinc and iron from canned fish was $1.2241 \mu \mathrm{g} / \mathrm{kg} \mathrm{bw} /$ day, $5.4634 \mu \mathrm{g} / \mathrm{kg} b w /$ day and $9.2231 \mu \mathrm{g} / \mathrm{kg}$ bw/day, respectively. Exposure of Serbian population to zinc, copper, and iron through consumption of canned fish is less than recommended daily reference intakes and there is no risk of reaching toxic levels by consuming fish.
\end{abstract}

\section{Introduction}

It is considered that eating fish has beneficial impact on human health. It is reach in omega-3 fatty acids, highly digestible good quality proteins containing all the essential amino acids and liposoluble vitamins (A and D), as well as vitamin $B_{12}$ [1]. Amounts of essential elements in fish, such as zinc, copper, and iron, are significant [2]. Although copper, zinc and iron have important biochemical functions, their excess can cause adverse health effects, as well as deficit. Copper and zinc are present in numerous metalloenzymes and co-factors [3]. Copper is present in numerous oxidative stress-related enzymes and enzymes involved in redox system [4]. However, copper generates superoxide and hydroxyl radicals, which are toxic and excessive exposure can lead to cellular damage. Copper intoxication could be related to Wilson's disease and development of Alzheimer's disease [5,6]. Zinc is involved in signal conversion and gen expression. If there is excess or deficit of zinc in the organism, it may affect cell function and multiplication, threatening cell survival, which may lead to disease [7]. Iron has an important role in major metabolic processes in the body, such as oxygen transfer, electron transfer and DNA synthesis [8]. Excess levels of iron in human body can lead to liver damage, and can affect pancre- as, heart, and lungs. It can lead to hormonal irregularities, diabetes mellitus, pancreatic hypertrophy and other health disorders [9].

Whether fish can be considered a significant source of zinc, copper, and iron? To obtain such an information it is needed to perform exposure assessment to these elements through fish consumption. Levels of exposure of population depends on fish consumption pattern and levels of these essential elements in fishery products in the local markets. Since Serbia does not have a developed fish production industry, mainly imported fish is consumed. Canned fish is cheaper, and it can be assumed that it is widely consumed. There is publication of essential elements exposure of Serbian population from canned fish consumption, but using SORS (Statistical Office Of Republic Serbia) data [10]. SORS includes only official data of imported fish, which may differ from real consumption. However, to estimate real exposure of the population to essential elements through canned fish consumption, it is needed to perform valid canned fish consumption survey. In order to obtain relevant data on food consumption, EFSA has issued a guide [11] which provides general principles on the collection of data on food consumption at the national level. 
The aim of this study was to provide a quantitative exposure assessment to essential elements through the consumption of canned fish in Serbia. This objective was fulfilled by analyzing content of essential elements in canned fish in period of five years (2014-2018) and by using data from a food consumption survey performed during 2018.

\section{Objects and methods}

\section{Consumption of fish and seafood}

Consumption survey of canned fish was designed and performed to general principles and EFSA guidelines on data collection of national food consumption [11]. The questionnaire was performed on 1,000 respondents. The tested population was similar in gender and age to the Serbian population. Average body weight of all interviewees was $71.3 \mathrm{~kg}$ which corresponds to recommendation given by EFSA to take $70 \mathrm{~kg}$ as average body weight of an adult European citizen, when unknown [12]. Demographic profile of tested population is given in Table 1 . The questionnaire was done anonymously during 2018 and all respondents were informed of the purpose of the survey. After excluding the respondents that do not consume canned fish (155), for further analyses left 845 fully answered questionnaires.

Table 1. Demographic profile of the sample $(\mathrm{N}=845)$

\begin{tabular}{|c|c|c|}
\hline \multirow{2}{*}{ Gender } & Male & $366(43.3 \%)$ \\
\hline & Female & $479(56.7 \%)$ \\
\hline \multirow{5}{*}{ Age } & Less than 24 years & $105(12.43 \%)$ \\
\hline & $25-34$ years & $154(18.22 \%)$ \\
\hline & $35-49$ years & $237(28.05 \%)$ \\
\hline & $50-64$ years & $240(28.40 \%)$ \\
\hline & Over 65 years & $109(12.90 \%)$ \\
\hline \multirow{2}{*}{ Weight } & Below $70 \mathrm{~kg}$ & $446(52.8 \%)$ \\
\hline & Above $70 \mathrm{~kg}$ & $399(47.2 \%)$ \\
\hline \multirow{2}{*}{ BMI } & $14.5 \leq \mathrm{BMI} \leq 24.9$ & $528(62.5 \%)$ \\
\hline & $\mathrm{BMI} \geq 24.9$ & 317 (37.5\%) \\
\hline \multicolumn{2}{|c|}{ Average body weight [kg] } & $71.3 \pm 10.4$ \\
\hline \multicolumn{2}{|c|}{ Average weekly consumption [g] } & $228.8 \pm 210.9$ \\
\hline
\end{tabular}

The questionnaire consisted of three sections. In the first section respondents were asked about general demographic information (sex, age, weight and height, and BMI was calculated later as $\mathrm{BMI}=$ weight $/$ height $^{2}$ ). The second section included questions about frequency of consumption of canned fish. In the third section the respondents were asked to recall their consumption of canned fish in the last seven days and to state the amount of consumed canned fish (in grams) in four defined categories (canned tuna, canned sardines, other canned sea fish or canned seafood). By choosing 7-day recall instead of 1-day recall, authors tried to avoid bias from dietary habits, according to EFSA recommendations.

\section{Samples}

Analyses were performed on 454 canned fish and seafood samples divided into four groups (canned tuna, canned sardines, canned other sea fish and canned seafood) during five consecutive years (2014-2018).

\section{Chemicals and Standards}

The chemicals were of analytical grade and supplied by Merck (Darmstadt, Germany): nitric acid 65\% and hydrogen peroxide 30\% (for analysis $\mathrm{EMSURE}^{\circledast} \mathrm{ISO}$ ). Deionized water (electrical resistivity $18.2 \mathrm{M} \Omega \mathrm{cm}^{-1}$ ) was obtained using the Simplicity ${ }^{\circledast}$ water purification system (Merck Millipore, Burlington MA, USA). For the quantification of copper, zinc, and iron certified standards were used (Certipur ${ }^{\varpi}$, Merck, Darmstadt, Germany) in concentrations of $1000 \mu \mathrm{g} \mathrm{mL} \mathrm{mL}^{-1}$. For quality control of the analytical procedure the certified reference material DORM-2 (dogfish muscle, NRC Canada) was used.

\section{Sample preparation}

After homogenization, test portion of about $0.5 \mathrm{~g}$ were used for further analyses. Into polytetrafluoroethylene (PTFE) vessels with test portions, $7 \mathrm{~mL}$ of nitric acid and $2 \mathrm{~mL}$ of hydrogen peroxide were added. Samples were mineralized in a microwave closed digestion system (Ethos Touch, Milestone, Italy). The following temperature program was used: heating up to $180{ }^{\circ} \mathrm{C}$ for $15 \mathrm{~min}$, followed by heating up to $220^{\circ} \mathrm{C}$ for $15 \mathrm{~min}$, and then heating up to $240^{\circ} \mathrm{C}$ for $10 \mathrm{~min}$, with a maximum power of $1000 \mathrm{~W}$. After digestion, solutions were quantitatively transferred into $50 \mathrm{~mL}$ volumetric flasks and diluted with deionized water.

\section{Instrumentation and analytical procedure}

Content of copper, zinc and iron was determined according EN14084:2003 [13]. Flame atomic absorption spectrometer (932 plus, GBC, Australia) was used.

\section{Method validation and assurance}

\section{of the quality of the results}

Validation of analytical procedure was performed according ISO/IEC17025:2017 [14] requirements, by determination of the following parameters: linearity, accuracy, precision, limit of detection (LOD) and limit of quantification (LOQ) (Table 2). Certified reference material (DORM-2, NRC Canada) was used for determination of accuracy and precision. Linearity is expressed as a correlation coefficient $\left(\mathrm{r}^{2}\right)$, accuracy as recovery, and precision as relative standard deviation in repeatability conditions $\left(\mathrm{RSD}_{\mathrm{r}}\right)$, and in reproducibility conditions $\left(\mathrm{RSD}_{\mathrm{R}}\right)$. LOD and LOQ were expressed as the analyte concentration corresponding to 3 times and 10 times, respectively, the standard deviation (SD) of 10 sample blanks.

\section{Table 2. Validation parameters}

\begin{tabular}{|c|c|c|c|c|c|c|}
\hline \multirow{2}{*}{ 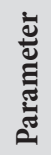 } & \multirow{2}{*}{ 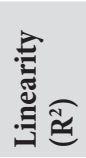 } & \multirow{2}{*}{ 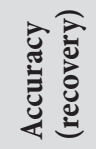 } & \multicolumn{2}{|c|}{ Precision } & \multirow{2}{*}{$\begin{array}{c}\text { LOD } \\
\left(\mathrm{mg} \mathrm{kg}^{-1}\right)\end{array}$} & \multirow{2}{*}{$\underset{\left(\mathrm{mg} \mathrm{kg}^{-1}\right)}{\mathrm{LOQ}}$} \\
\hline & & & RSDr & $\mathrm{RSD}_{\mathrm{R}}$ & & \\
\hline $\mathrm{Cu}$ & 1.00 & $95 \%$ & $4.7 \%$ & $5.9 \%$ & 0.30 & 1.00 \\
\hline $\mathrm{Zn}$ & 1.00 & $90 \%$ & $4.3 \%$ & $6.6 \%$ & 0.25 & 1.00 \\
\hline $\mathrm{Fe}$ & 0.99 & $102 \%$ & $4.4 \%$ & $8.4 \%$ & 0.30 & 1.00 \\
\hline
\end{tabular}


Assurance of the quality of the results were provided by analyzing CRM (DORM-2, NRC Canada) within every sample set. The obtained results were monitored through control charts. If recovery of CRM was within satisfactory range, results of all samples in the sample set were accepted, if it was not, all samples were analyzed again.

\section{Exposure estimation}

Obtained results from the analyses of levels of copper, zinc and iron in canned fish and results from the canned fish consumption survey were combined to estimate exposure of Serbian population to these elements through eating canned fish. Estimation was calculated according following equation [15]:

$$
\mathrm{EDI}=\frac{\sum_{\mathrm{i}=1}^{\mathrm{n}} \mathrm{F}_{\mathrm{i}}}{7} \times \frac{1}{\mathrm{bw}} \times \mathrm{C}_{\mathrm{t}}
$$

EDI is the estimated daily intake of $\mathrm{Cu} / \mathrm{Zn} / \mathrm{Fe}[\mu \mathrm{g} / \mathrm{kg}$ bw/day]. $F_{i}$ is the amount of canned fish consumed weekly $[\mathrm{kg}]$. Body weight (bw) is taken to be $70 \mathrm{~kg}$ as recommended by EFSA for adult European citizen (EFSA, 2012a). $C_{t}$ is the concentration of $\mathrm{Cu} / \mathrm{Zn} / \mathrm{Fe}[\mu \mathrm{g} / \mathrm{kg}]$.

To assess exposure, with including the variability of the population, the Monte Carlo simulation, as one of the most common methods [16], was used.

\section{Statistical methods}

Canned fish consumption patterns of demographic groups (defined by sex, age, weight, and BMI) were compared by Chi-square test for association. An independent sample t-test was used for analyzing average consumption with statistical significance of 0.05 .
For estimation the intake of copper, zinc and iron from canned fish consumption, the Monte Carlo analysis of 100,000 simulations was used. Calculating levels of $\mathrm{Cu} / \mathrm{Zn} /$ Fe was based on their mean values (Table 4). According FAO/WHO [17] it can be assumed that an individual exposure over time is equal to this level.

Minitab was used for probability distribution fitting for body weight and weekly intake of canned fish and for Monte Carlo simulation. For fitting of the probability distributions visual analysis was equally considered [18].

\section{Results and discussion}

Consumption of canned fish

Frequency consumption patterns for canned fish obtained from consumption survey are given in Table 3 . Obtained average weekly consumption of canned fish is $228.8 \mathrm{~g}$ (Table 1). It confirms our assumption that consumption of canned fish is significant in Serbia.

Relationships between canned fish consumption patterns and demographic characteristics of the sample were tested (Chi-square test for association). On average, depending on the demographic group, consumption on a weekly basis was confirmed by $26.3 \%$ to $62.0 \%$ of interviewed consumers. This study showed significant association between sex, BMI and weight and consumption patterns $(\mathrm{p}<0.05)$. Male respondents, respondents with weight over $70 \mathrm{~kg}$ and with BMI $>24.9$ eat canned fish more frequently than females, consumers with weight below $70 \mathrm{~kg}$ and with "ideal" BMI. There were no

Table 3. Frequency of consumption of canned fish (tuna, sardine, sea fish, seafood)

\begin{tabular}{|c|c|c|c|c|}
\hline Gender & On a weekly basis & On a monthly basis & Once a year or less & Total \\
\hline Female & $126(26.3 \%)$ & $49(10.2 \%)$ & $304(63.5 \%)$ & $479(100 \%)$ \\
\hline Male & $227(62.0 \%)$ & $33(9.0 \%)$ & $106(29.0 \%)$ & $366(100 \%)$ \\
\hline \multicolumn{5}{|l|}{$\chi^{2}=114.557 ; p<0.05$} \\
\hline Below 70 kg & $134(30.1 \%)$ & $43(9.6 \%)$ & $269(60.3 \%)$ & $446(100 \%)$ \\
\hline Above $70 \mathrm{~kg}$ & $219(54.9 \%)$ & $39(9.8 \%)$ & $141(35.3 \%)$ & $399(100 \%)$ \\
\hline \multicolumn{5}{|l|}{$\chi^{2}=58.189 ; p<0.05$} \\
\hline BMI (14-5-24.9) & $201(38.1 \%)$ & $48(9.1 \%)$ & $279(52.8 \%)$ & $528(100 \%)$ \\
\hline $\mathrm{BMI}<14.5$ / $\mathrm{BMI}>24.9$ & $152(47.9 \%)$ & $34(10.7 \%)$ & $131(41.3 \%)$ & $317(100 \%)$ \\
\hline \multicolumn{5}{|l|}{$\chi^{2}=10.589 ; p<0.05$} \\
\hline Below 35 & $103(39.9 \%)$ & $23(8.9 \%)$ & $132(51.2 \%)$ & $258(100 \%)$ \\
\hline $35-49$ & $104(43.7 \%)$ & $26(10.9 \%)$ & $108(45.4 \%)$ & $238(100 \%)$ \\
\hline Above 50 & $146(41.8 \%)$ & $33(9.5 \%)$ & $170(48.7 \%)$ & $349(100 \%)$ \\
\hline$\chi^{2}=1.834 ; p>0.05$ & & & & \\
\hline
\end{tabular}

Table 4. Concentration of essential elements in canned fish

\begin{tabular}{|c|c|c|c|c|c|c|}
\hline & & Canned Tuna & Canned sardine & Canned sea fish & Canned seafood & ALL \\
\hline \multirow{3}{*}{ Copper } & Number of samples (positive samples) & $276(69)$ & $122(105)$ & $54(47)$ & $2(1)$ & $454(222)$ \\
\hline & Mean $\left[\mathrm{mg} \mathrm{kg}^{-1}\right]$ & 0.769 & 2.100 & 1.931 & 1.565 & 1.268 \\
\hline & Range $\left[\mathrm{mg} \mathrm{kg}^{-1}\right]$ & $0.5-3.08$ & $0.5-6.49$ & $0.5-3.11$ & $0.5-2.63$ & $0.5-6.49$ \\
\hline \multirow{3}{*}{ Zinc } & Number of samples (positive samples) & $276(276)$ & $122(122)$ & $54(54)$ & $2(2)$ & $454(454)$ \\
\hline & Mean $\left[\mathrm{mg} \mathrm{kg}^{-1}\right]$ & 4.824 & 7.382 & 6.016 & 6.395 & 5.661 \\
\hline & Range $\left[\mathrm{mg} \mathrm{kg}^{-1}\right]$ & $1.92-8.7$ & $2.9-37.2$ & $2.61-8.64$ & $4.11-8.68$ & $1.92-37.2$ \\
\hline \multirow{3}{*}{ Iron } & Number of samples (positive samples) & $276(276)$ & $122(122)$ & $54(54)$ & $2(2)$ & $454(454)$ \\
\hline & Mean $\left[\mathrm{mg} \mathrm{kg}^{-1}\right]$ & 8.401 & 11.607 & 10.848 & 9.005 & 9.556 \\
\hline & Range [mg kg-1] & $1.3-13.9$ & $2.71-21.8$ & $2.11-15.4$ & $6.91-11.1$ & $1.3-21.8$ \\
\hline
\end{tabular}


statistically significant association between age groups $(\mathrm{p}>0.05)$.

\section{Levels of copper, zinc, and iron in canned fish}

Copper, zinc, and iron determination were done in 452 samples of canned fish and 2 samples of canned seafood. Obtained concentrations of copper, zinc and iron in canned fish and seafood are given in Table 4.

Zinc and iron were found in all 454 samples (100\%), and copper in 222 samples (48.9\%). Values of copper below the LOQ were substituted with a constant value of LOQ/2 for further analyses, as it is recommended [19]. Monte Carlo uncertainty analysis of $95 \%$ CI of the mean values shows that such results have little effect on the upper percentile exposures [20]. The average obtained concentration in all samples were $1.268 \mathrm{mg} \mathrm{kg}^{-1}$ for $\mathrm{Cu}, 5.661 \mathrm{mg} \mathrm{kg}^{-1}$ for $\mathrm{Zn}$, and $9.556 \mathrm{mg} \mathrm{kg}^{-1}$ for Fe. The highest concentration for all of three minerals were found in canned sardines $(\mathrm{Cu}-6.49$ $\mathrm{mg} \mathrm{kg}{ }^{-1}, \mathrm{Zn}-37.2 \mathrm{mg} \mathrm{kg}^{-1}$, and $\left.\mathrm{Fe}-21.8 \mathrm{mg} \mathrm{kg}^{-1}\right)$, as well as the highest average concentrations $\left(\mathrm{Cu} 2.100 \mathrm{mg} \mathrm{kg}^{-1}\right.$, Zn $7.382 \mathrm{mg} \mathrm{kg}^{-1}$, and Fe $\left.11.607 \mathrm{mg} \mathrm{kg}^{-1}\right)$.

There are two published investigations of levels of $\mathrm{Cu}, \mathrm{Zn}$ and Fe in canned fish from Serbian local markets. Popovic et al. [10] performed analyses in 207 samples of canned tuna, sardines and mackerel and Novakov et al. [21] in 98 samples of canned tuna, sardines and sprouts. Popovic et al. [10] found the highest average concentration for all the three minerals in canned sardines, which was in line with our results. Found levels $\left(\mathrm{Cu}-1.28 / 1.37 \mathrm{mg} \mathrm{kg}^{-1}\right.$ oil/tomato sauce, $\mathrm{Zn}-$ 15.1/14.05 $\mathrm{mg} \mathrm{kg}^{-1}$, and $\mathrm{Fe}-13.8 / 16.78 \mathrm{mg} \mathrm{kg}^{-1}$ ) were lower than ours for $\mathrm{Cu}$, but significantly higher for $\mathrm{Zn}$ and $\mathrm{Fe}$. On the other hand, Novakov et al. [21] reported higher levels of $\mathrm{Cu}$ and $\mathrm{Zn}$ in canned tuna $\left(2.60 \mathrm{mg} \mathrm{kg}^{-1}, 21.96 \mathrm{mg} \mathrm{kg}^{-1}\right.$, respectively) than in canned sardines $\left(2.49 \mathrm{mg} \mathrm{kg}^{-1}, 18.21 \mathrm{mg}\right.$ $\mathrm{kg}^{-1}$, respectively), but higher level of $\mathrm{Fe}$ in canned sardines $\left(21.98 \mathrm{mg} \mathrm{kg}^{-1}\right)$ then in canned tuna $\left(20.36 \mathrm{mg} \mathrm{kg}^{-1}\right)$. All results are significantly higher than ours, except for $\mathrm{Cu}$, which is in line for canned sardines and little higher in canned tuna.

Authors from other countries reported different levels of the elements. Lower levels of $\mathrm{Cu}$ in canned sardines are reported by authors from Croatia $\left(0.88 \mathrm{mg} \mathrm{kg}^{-1}\right)$ [22], Spain (0.513-0.898 $\left.\mathrm{mg} \mathrm{kg}^{-1}\right)$ [23], Turkey $\left(1.024 \mathrm{mg} \mathrm{kg}^{-1}\right)$ [24], Iraq $\left(0.7-2.1 \mathrm{mg} \mathrm{kg}^{-1}\right)$ [25], and Nigeria $\left(0.01 \mathrm{mg} \mathrm{kg}^{-1}\right)$ [26], but results from USA (0.83 $\left.\mathrm{mg} \mathrm{kg}^{-1}\right)$ [27], and Brazil (1.31-2.25 mg $\left.\mathrm{kg}^{-1}\right)$ [28] are in line with our results. In canned tuna, authors from Spain $\left(0.483 \mathrm{mg} \mathrm{kg}^{-1}\right)$ [23], Turkey $\left(0.604 \mathrm{mg} \mathrm{kg}^{-1}\right)$ [24], and USA $\left(0.25 \mathrm{mg} \mathrm{kg}^{-1}\right)$ [25] found levels lower than ours. Reported levels of $\mathrm{Zn}$ in canned sardines are higher than ours from Croatia $\left(18 \mathrm{mg} \mathrm{kg}^{-1}\right)$ [22], Turkey $\left(23.267 \mathrm{mg} \mathrm{kg}^{-1}\right)$ [24], USA (11.45 $\mathrm{mg} \mathrm{kg}^{-1}$ ) [27], and Brazil (16.16-36.09 $\mathrm{mg} \mathrm{kg}^{-1}$ ) [28], and lower than ours from Spain (4.329-6.767 mg kg-1) [23], and Nigeria (0.09-4.49 $\left.\mathrm{mg} \mathrm{kg}^{-1}\right)$ [26]. Regarding canned tuna, levels of $\mathrm{Zn}$ reported by authors from Turkey $(10.802 \mathrm{mg}$ $\left.\mathrm{kg}^{-1}\right)$ [24] and Lebanon (7.49 $\left.\mathrm{mg} \mathrm{kg}^{-1}\right)$ [29] are higher, from Spain $\left(2.27 \mathrm{mg} \mathrm{kg}^{-1}\right)$ [23] is lower, and from USA (4.78 $\mathrm{mg} \mathrm{kg}^{-}$ 1) [27] is in line with our results. Levels of Fe found in canned sardines by authors from Croatia (19 $\left.\mathrm{mg} \mathrm{kg}^{-1}\right)$ [22], Turkey [24], Iraq [25] and Brazil [28] are higher (22.162 $\mathrm{mg} \mathrm{kg}^{-1}, 20-$ $30 \mathrm{mg} \mathrm{kg}^{-1}$ and $20.96-88.83 \mathrm{mg} \mathrm{kg}^{-1}$, respectively), and from Nigeria [26] (8.04-48.18 $\left.\mathrm{mg} \mathrm{kg}^{-1}\right)$, and USA [27] (12.7 $\left.\mathrm{mg} \mathrm{kg}^{-1}\right)$ in line with ours. In canned tuna reported level for Fe by authors from USA (15.8 $\left.\mathrm{mg} \mathrm{kg}^{-1}\right)$ [28] is higher, and from Turkey $\left(8.105 \mathrm{mg} \mathrm{kg}^{-1}\right)$ [24] is in line with our result.

\section{Exposure assessment}

According to our research on the level of minerals in canned fish and eating habits of the Serbian population, mean estimated daily intake of copper, zinc and iron in canned fish were $1.2241 \mu \mathrm{g} / \mathrm{kg}$ bw/day, $5.4634 \mu \mathrm{g} / \mathrm{kg}$ bw/day, and $9.2231 \mu \mathrm{g} / \mathrm{kg}$ bw/day, respectively (Table 5). Estimated total daily intake of the three minerals after a Monte Carlo analysis of 100,000 simulations is shown in Figures 1a-c.

Table 5. Estimated daily intake of copper, zinc and iron in canned fish

\begin{tabular}{|l|c|c|c|} 
& $\begin{array}{c}\text { Copper } \\
{[\mu \mathrm{g} / \mathrm{kg} \mathrm{bw} / \mathrm{d}]}\end{array}$ & $\begin{array}{c}\text { Zinc } \\
{[\mu \mathrm{g} / \mathrm{kg} \mathrm{bw} / \mathrm{d}]}\end{array}$ & $\begin{array}{c}\text { Iron } \\
{[\mu \mathrm{g} / \mathrm{kg} \mathrm{bw} / \mathrm{d}]}\end{array}$ \\
\hline Mean & 1.2241 & 5.4634 & 9.2231 \\
\hline $5^{\text {th }}$ percentile & 0.454 & 2.043 & 3.373 \\
\hline $1^{\text {st }}$ quartile & 0.763 & 3.404 & 5.746 \\
\hline $3^{\text {rd }}$ quartile & 1.549 & 6.913 & 11.669 \\
\hline $9^{\text {th }}$ percentile & 3.586 & 16.201 & 26.936 \\
\hline
\end{tabular}

\begin{tabular}{|l|l|l|l|}
$95 \%$ confidence & $1.2203-1.2279$ & $5.4465-5.4803$ & $9.1946-9.2516$
\end{tabular}
\begin{tabular}{ll|l|l|}
\hline interval of mean & $1.2203-1.2279$ & $5.4465-5.4803$ & $9.1946-9.2516$
\end{tabular} All values are derived from a Monte Carlo simulation.

Similar investigation of contribution of $\mathrm{Cu}, \mathrm{Zn}$ and Fe from fish to dietary intake in Serbia was performed by Popovic et al. [10]. Investigation included canned fish (tuna, sardines, and mackerel in oil and in tomato sauce). Results were expressed as\%RDA for men and women for each type of fish separately. Reported EDI for $\mathrm{Cu}$ were in range 0.28 $0.46 \%$ RDA, EDI for Zn were in range $0.21-0.57 \%$ RDA and EDI for Fe were in range $0.14-0.64 \%$ RDA. The authors concluded that levels of $\mathrm{Cu}, \mathrm{Zn}$ and $\mathrm{Fe}$ in canned fish do not represent any health risk, and even do not represent important dietary source of $\mathrm{Cu}, \mathrm{Zn}$ and Fe. Reported EDI of $\mathrm{Cu}(1.671 \mu \mathrm{g} / \mathrm{kg} \mathrm{bw} /$ day $)$ and $\mathrm{Zn}(6.629 \mu \mathrm{g} / \mathrm{kg}$ bw/day $)$ in fish from Spain, were slightly higher than our results [30].

Provisional maximum tolerable daily intake (PMTDI) established by JECFA for $\mathrm{Cu}$ is $0.5 \mathrm{mg} / \mathrm{kg}$ bw/day [31], for $\mathrm{Zn}$ is $0.3-1 \mathrm{mg} / \mathrm{kg}$ bw/day [32] and for Fe is $0.8 \mathrm{mg} / \mathrm{kg} \mathrm{bw} /$ day [33]. According Regulation EU EC [34], recommended daily reference intakes for $\mathrm{Cu}, \mathrm{Zn}$ and $\mathrm{Fe}$ for adults are $1 \mathrm{mg}$ (i. e. $14.286 \mu \mathrm{g} / \mathrm{kg}$ bw/d), $10 \mathrm{mg}$ (i. e. $142.857 \mu \mathrm{g} / \mathrm{kg}$ bw/d) and $14 \mathrm{mg}$ (i. e. $200.000 \mu \mathrm{g} / \mathrm{kg}$ bw/d), respectively. According to our results mean estimated daily intake of the minerals from canned fish is below recommended levels $(0.175 \%$ RDA Cu, 7.805\% RDA $\mathrm{Zn}$ and $18.446 \%$ RDA $\mathrm{Fe})$. Moreover, in the «best case scenario», if we take into account the values for the $95^{\text {th }}$ percentile, the population does not get enough of these minerals through canned fish. Obtained values for $95^{\text {th }}$ percentile are $0.025 \%$ RDA for $\mathrm{Cu}$, $0.011 \%$ RDA for $\mathrm{Zn}$ and $0.013 \%$ RDA for Fe. 

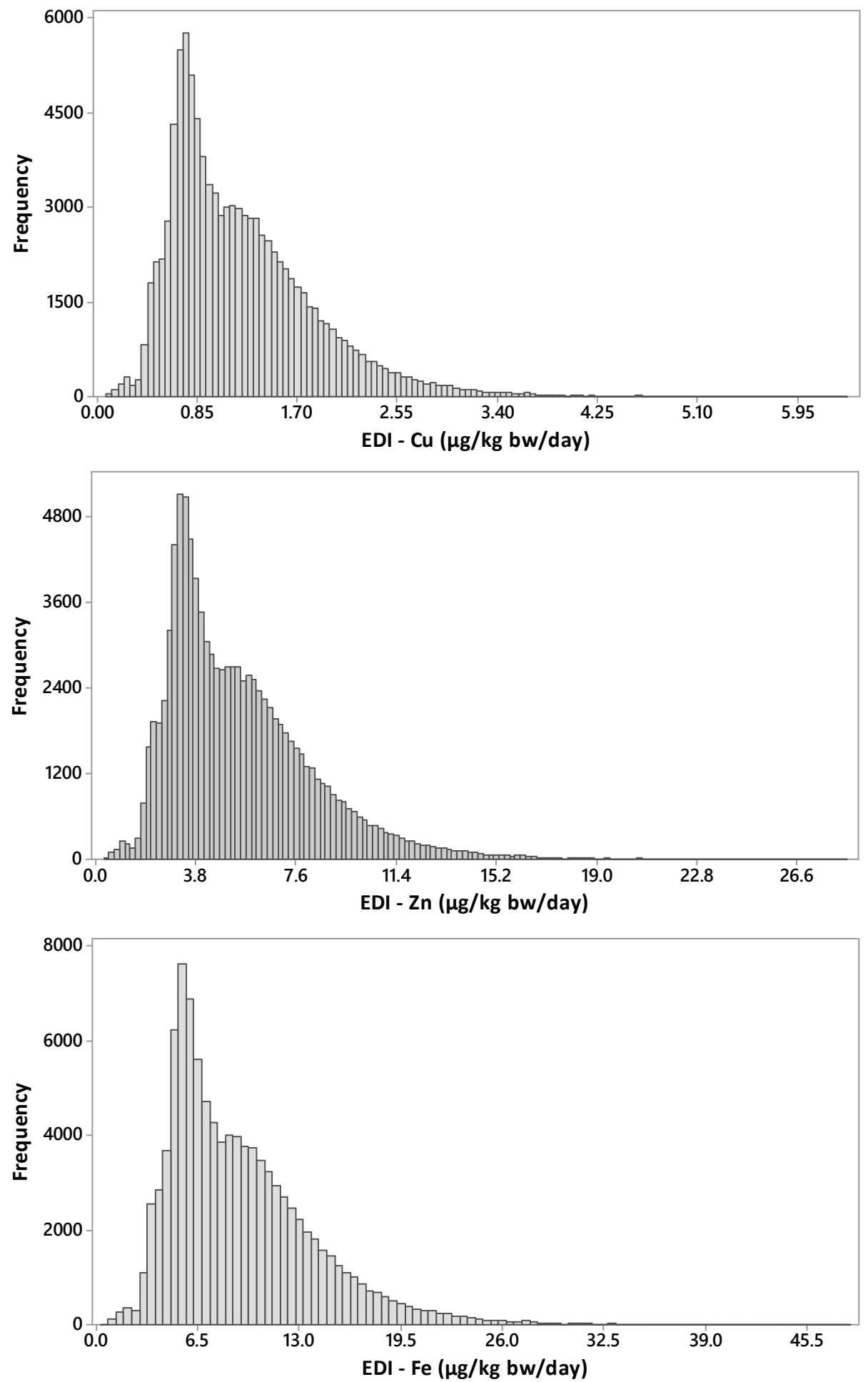

Figure 1. Estimated total daily intake of Copper, Zinc, and Iron after a Monte Carlo analysis of 100,000 simulations

Obtained results indicates that there is no risk of exposure to the toxic values of copper, zinc and iron through canned fish consumption and, moreover, canned fish does not represent source of these three essential minerals.

\section{Conclusion}

Consumption of canned fish is significant in Serbia $(228.8 \mathrm{~g} / \mathrm{w})$. On average, depending on the demographic group, consumption on a weekly basis was confirmed by $26.3 \%$ to $62.0 \%$ of interviewed consumers. Male respondents, respondents with weight over $70 \mathrm{~kg}$ and with $\mathrm{BMI}>24.9$ eat canned fish more frequently than females, consumers with weight below $70 \mathrm{~kg}$ and with "ideal" BMI. There were no statistically significant association between age groups.

Copper was detected in $49 \%$ of tested samples, where zinc and iron were found in all the tested samples. The highest levels of all three essential elements were found in canned sardines.

Exposure of Serbian population to zinc, copper, and iron through consumption of canned fish is less than recommended daily reference intakes and there is no risk of reaching toxic levels by consuming fish. 


\section{REFERENCES}

1. Larsen, R., Eilertsen, K. -E., Elvevoll, E. 0.(2011). Health benefits of marine foods and ingredients. Biotechnology Advances, 29(5), 508-518. https://doi.org/10.1016/j.biotechadv.2011.05.017

2. Fraga, C. G. (2005). Relevance, essentiality and toxicity of trace elements in human health. Molecular Aspects of Medicine, 26(4-5 SPEC. ISS.), 235-244. https://doi.org/10.1016/j. mam.2005.07.013

3. Osredkar, J., Sustar, N. (2011). Copper and zinc, biological role and significance of copper/zinc imbalance. Journal of Clinical Toxicology, s3:001. https://doi.org/10.4172/2161-0495. S3-001

4. Stern, B. R. (2010). Essentiality and toxicity in copper health risk assessment: Overview, update and regulatory considerations. Journal of Toxicology and Environmental Health - Part A: Current Issues, 73 (2-3), 114-127. https://doi.org/10.1080/15287390903337100

5. ATSDR. (2002.). Toxicological profile for copper. U. S. Department of health and humans services, Public health service, Centres for diseases control, Atlanta, USA.

6. Tchounwou, P. B., Newsome, C., Williams, J., Glass, K. (2008). Copper-induced cytotoxicity and transcriptional activation of stress genes in human liver carcinoma (HepG(2)) cells. Metal lons in Biology and Medicine, 10, 285-290.

7. Oteiza, P. I., Clegg, M. S., Zago, M. P., Keen, C. L. (2000). Zinc deficiency induces oxidative stress and AP-1 activation in 3T3 cells. Free Radical Biology and Medicine, 28(7), 1091-1099. https://doi.org/10.1016/S0891-5849(00)00200-8

8. Evans, P., Halliwell, B. (2001). Micronutrients: Oxidant/antioxidant status. British Journal of Nutrition, 85(SUPPL. 2), S67S74. https://doi.org/10.1079/bjn2000296

9. Kang, J. O. (2001). Chronic iron overload and toxicity: Clinical chemistry perspective. Clinical Laboratory Science: Journal of the American Society for Medical Technology, 14(3), 209-219; quiz 222.

10. Popović, A. R., Relić, D. J., Vranić, D. V., Babić-Milijašević, J. A., Pezo, L. L., Đinović-Stojanović, J. M. (2018). Canned sea fish marketed in serbia: Their zinc, copper, and iron levels and contribution to the dietary intake. Arhiv Za Higijenu Rada i Toksikologiju, 69(1), 55-60. https://doi.org/10.2478/aiht-2018-69-3069 11. European Food Safety Authority. (2009). General principles for the collection of national food consumption data in the view of a pan-European dietary survey. EFSA Journal, 7(12), Article 1435. https://doi.org/10.2903/j.efsa.2009.1435

12. EFSA Scientific Committee. (2012). Guidance on selected default values to be used by the EFSA scientific committee, scientific panels and units in the absence of actual measured data. EFSA Journal, 10(3), Article 2579. https://doi.org/10.2903/j.efsa.2012.2579

13. EN14084:2003 "Foodstuffs - Determination of trace elements - Determination of lead, cadmium, zinc, copper and iron by atomic absorption spectrometry (AAS) after microwave digestion" ICS Code (General methods of tests and analysis for food products): 67.050 . CEN,2003.

14. ISO/IEC17025:2017 "General requirements for the competence of testing and calibration laboratories". Technical Committee: ISO/CASCO Committee on conformity assessment. Publication date: 2017-11. Corrected version (fr): 2018-04.

15. Pacin, A. M., Resnik, S. L., Martinez, E. J. (2011). Concentrations and exposure estimates of deoxynivalenol in wheat products from Argentina. Food Additives and Contaminants: Part B Surveillance, 4(2), 125-131. https://doi.org/10.1080/1939321 0.2011 .564401

16. Lindboe, M., Henrichsen, E. N., Høgasen, H. R., Bernhoft, A. (2012). Lead concentration in meat from lead-killed moose and predicted human exposure using Monte Carlo simulation. Food Additives and Contaminants - Part A Chemistry, Analysis, Control, Exposure and Risk Assessment, 29(7), 1052-1057. https://doi.org/10.1080/19440049.2012.680201

17. FAO/WHO. (2009). Principles and Methods for the Risk Assessment of Chemicals in Food. In Environmental Health, Criteria 240. Food and Agriculture Organization of the United Nations \&World Health Organization: Geneva, Switzerland.

18. Morales, J. S. S., Rojas, R. M., Pérez-Rodríguez, F., Casas, A. A., López, M. A. A. (2011). Risk assessment of the lead intake by consumption of red deer and wild boar meat in Southern Spain. Food Additives and Contaminants - Part A Chemistry, Analysis, Control, Exposure and Risk Assessment, 28(8), 1021-1033. https://doi.org/10.1080/19440049.2011.583282
19. Beal, S. L. (2001). Ways to fit a PK model with some data below the quantification limit. Journal of Pharmacokinetics and Pharmacodynamics, 28(5), 481-504. https://doi. org/10.1023/A:1012299115260

20. Djekic, I., Petrovic, J., Jovetic, M., Redzepovic-Djordjevic, A., Stulic, M., Lorenzo, J. M. et al. (2020). Aflatoxins in milk and dairy products: Occurrence and exposure assessment for the Serbian population. Applied Sciences (Switzerland), 10(21), Article 7420, 1-17. https://doi.org/10.3390/app10217420

21. Novakov, N. J., Mihaljev, Ž. A., Kartalović, B. D., Blagojević, B. J., Petrović, J. M., Ćirkovíć, M. A. et al. (2017). Heavy metals and PAHs in canned fish supplies on the Serbian market. Food Additives and Contaminants: Part B Surveillance, 10(3), 208-215. https://doi.org/10.1080/19393210.2017.1322150

22. Bilandžić, N., Sedak, M., Čalopek, B., Đokić, M., Varenina, I., Kolanović, B. S. et al. (2018). Element contents in commercial fish species from the Croatian market. Journal of Food Composition and Analysis, 71, 77-86. https://doi.org/10.1016/j.jfca.2018.02.014

23. Olmedo, P., Hernández, A. F., Pla, A., Femia, P., Navas-Acien, A., Gil, F. (2013). Determination of essential elements (copper, manganese, selenium and zinc) in fish and shellfish samples. Risk and nutritional assessment and mercury-selenium balance. Food and Chemical Toxicology, 62, 299-307. https://doi. org/10.1016/j.fct.2013.08.076

24. Mol, S. (2011). Levels of heavy metals in canned bonito, sardines, and mackerel produced in Turkey. Biological Trace Element Research, 143(2), 974-982. https://doi.org/10.1007/s12011010-8909-5

25. Ahmed, S. S., Hasan, M. A. (2019). Determination of some heavy metals in three fish species from Duhok City Markets in Kurdistan of Iraq. Science Journal of University of Zakho, 7(4), 152-157. https://doi.org/10.25271/sjuoz.2019.7.4.621

26. Iwegbue, C. M. A., Nwajei, G. E., Arimoro, F. O., Eguavoen, 0. (2009). Characteristic levels of heavy metals in canned sardines consumed in Nigeria. Environmentalist, 29(4), 431-435. https://doi.org/10.1007/s10669-009-9233-5

27. Ikem, A., Egiebor, N. 0. (2005). Assessment of trace elements in canned fishes (mackerel, tuna, salmon, sardines and herrings) marketed in Georgia and Alabama (United States of America). Journal of Food Composition and Analysis, 18(8), 771-787. https://doi.org/10.1016/j.jfca.2004.11.002

28. Tarley, C. R. T., Coltro, W. K. T., Matsushita, M., De Souza, N. E. (2001). Characteristic levels of some heavy metals from Brazilian canned sardines (sardinella brasiliensis). Journal of Food Composition and Analysis, 14(6), 611-617. https://doi.org/10.1006/jfca.2001.1028

29. Al Ghoul, L., Abiad, M. G., Jammoul, A., Matta, J., El Darra N. (2020). Zinc, aluminium, tin and Bis-phenol a in canned tuna fish commercialized in Lebanon and its human health risk assessment. Heliyon, 6(9), Article e04995. https://doi.org/10.1016/j. heliyon.2020.e04995

30. Olmedo, P., Pla, A., Hernández, A. F., Barbier, F., Ayouni, L., \& Gil, F. (2013). Determination of toxic elements (mercury, cadmium, lead, tin and arsenic) in fish and shellfish samples. Risk assessment for the consumers. Environment International, 59, 63 72. https://doi.org/10.1016/j.envint.2013.05.005

31. JECFA Report TRS683-JECFA 26/31. Retrieved from https://apps.who.int/food-additives-contaminants-jecfa-database/chemical.aspx?chemID=2824 Accessed June 15, 2021 32. JECFA Report TRS683-JECFA-26/32. Retrieved from https://www.worldcat.org/title/evaluation-of-certain-food-additives-and-contaminants-27-report-of-the-joint-faowho-expertcommittee-on-food-additives/oclc/260130277 \& referer=brief results Accessed June 15, 2021

33. JECFA Report TRS696-JECFA-27/29. Retrieved from https://apps.who.int/food-additives-contaminants-jecfa-database/chemical.aspx?chemID=2859 Accessed June 15, 2021 34. No, E. (1169/2011). Regulation of the European Parliament and of the Council of $\mathbf{2 5}$ October 2011 on the provision of food information to consumers, amending Regulations (EC) No 1924/2006 and (EC) No 1925/2006 of the European Parliament and of the Council, and repealing Commission Directive 87/250/EEC, Council Directive 90/496/EEC, Commission Directive 1999/10/EC Directive 2000/13/EC of the European Parliament and of the Council, Commission Directives 2002/67/EC and 2008/5/EC and Commission Regulation (EC) No 608/2004. 


\section{AUTHOR INFORMATION}

Jelena Petrovic — MSc, Analyst, Department of Instrumental Chemistry, Center for Food Analysis. 11, Zmaja od Nocaja, 11000, Belgrade, Serbia. E-mail: jelena.petrovic@cin.co.rs

ORCID: https://orcid.org/0000-0002-5969-9974

Milica Jovetic — PhD, Analyst, Head of Department of Instrumental Chemistry, Center for Food Analysis. 11, Zmaja od Nocaja, 11000, Belgrade, Serbia.E-mail:milica.jovetic@cin.co.rs

ORCID: https://orcid.org/0000-0003-0909-4122

Milica Štulić - MSc, Analyst, Department of Instrumental Chemistry, Center for Food Analysis. 11, Zmaja od Nocaja, 11000, Belgrade, Serbia. E-mail: milicav@cin.co.rs

ORCID: https://orcid.org/0000-0001-6227-9973

Azra Redžepović-Đorđević - MSc, Analyst, Department of Instrumental Chemistry, Center for Food Analysis. 11, Zmaja od Nocaja, 11000, Belgrade, Serbia.E-mail: azra@cin.co.rs

ORCID: https://orcid.org/0000-0002-6000-5431

Dragan Vujadinović - PhD, Associate professor, the Dean, Faculty of Technology Zvornik, University of East Sarajevo, 30, Vuka Karadžića, 71126 Lukavica, East Sarajevo, Republic of Srpska, Bosnia and Herzegovina. E-mail: dragan.vujadinovic@tfzv.ues.rs.ba ORCID: https://orcid.org/0000-0002-3809-4415

Ilija V. Djekic — PhD, full professor, Department for Food Safety and Quality Management, Faculty of Agriculture, University of Belgrade. 6 Nemanjina, Zemun, 11080, Belgrade, Serbia.E-mail: idjekic@agrif.bg.ac.rs

ORCID: https://orcid.org/0000-0002-8132-8299

Igor B. Tomasevic - PhD, associate professor, Animal Source Food Technology Department, Faculty of Agriculture, University of Belgrade. 6 Nemanjina, Zemun, 11080, Belgrade, Serbia.E-mail: tbigor@agrif.bg.ac.rs

ORCID: https://orcid.org/0000-0002-1611-2264

* corresponding author

All authors bear responsibility for the work and presented data.

All authors made an equal contribution to the work.

The authors were equally involved in writing the manuscript and bear the equal responsibility for plagiarism.

The authors declare no conflict of interest. 